University of Wollongong

Research Online

Faculty of Engineering - Papers (Archive)

Faculty of Engineering and Information

Sciences

$1-1-2009$

\title{
Flame spray-pyrolyzed vanadium oxide nanoparticles for lithium battery cathodes
}

See How $\mathrm{Ng}$

University of Wollongong, shn076@uow.edu.au

T J. Patey

Paul Scherrer Institut, Switzerland

R Buchel

Dep. Mechanical Process Eng. Switzerland

F Krumeich

Lab of Inorganic Chemistry, Switzerland

Jiazhao Wang

University of Wollongong, jiazhao@uow.edu.au

See next page for additional authors

Follow this and additional works at: https://ro.uow.edu.au/engpapers

Part of the Engineering Commons

https://ro.uow.edu.au/engpapers/2651

\section{Recommended Citation}

Ng, See How; Patey, T J.; Buchel, R; Krumeich, F; Wang, Jiazhao; Liu, Hua-Kun; Pratsinis, S E.; and Novak, P: Flame spray-pyrolyzed vanadium oxide nanoparticles for lithium battery cathodes 2009, 3748-3755. https://ro.uow.edu.au/engpapers/2651 


\section{Authors}

See How Ng, T J. Patey, R Buchel, F Krumeich, Jiazhao Wang, Hua-Kun Liu, S E. Pratsinis, and P Novak 
DOI:10.1039/B821389P (Paper) Phys. Chem. Chem. Phys., 2009, 11, 3748-3755

\title{
Flame spray-pyrolyzed vanadium oxide nanoparticles for lithium battery cathodes
}

\author{
See-How Ng ${ }^{a d}$, Timothy J. Patey ${ }^{a}$, Robert Büchel ${ }^{b}$, Frank Krumeich $^{c}$, Jia-Zhao Wang $^{d}$, Hua-Kun Liu ${ }^{d}$, Sotiris E. Pratsinis ${ }^{b}$ and Petr \\ Novák $*^{a}$ \\ ${ }^{a}$ Electrochemistry Laboratory, Paul Scherrer Institut, CH-5232, Villigen PSI, Switzerland. E-mail: petr.novak@psi.ch; Fax: +41 56 310 4415; \\ Tel: +41563102457 \\ ${ }^{b}$ Particle Technology Laboratory, Department of Mechanical and Process Engineering, ETH Zürich, CH-8092, Zürich, Switzerland \\ ${ }^{c}$ Institute for Inorganic Chemistry, ETH Zürich, CH-8093, Zürich, Switzerland \\ ${ }^{d}$ Institute for Superconducting and Electronic Materials, and ARC Center of Excellence for Electromaterials Science, University of \\ Wollongong, NSW 2522, Australia
}

Received 28th November 2008, Accepted 18th February 2009

First published on the web 14th March 2009

\begin{abstract}
Vanadium pentoxide $\left(\mathrm{V}_{2} \mathrm{O}_{5}\right)$ nanoparticles $(30-60 \mathrm{~nm})$ were made by a one-step and scalable flame spray pyrolysis (FSP) process. Optimization of the FSP processing conditions (precursor concentration and injection rate) enhanced the electrochemical performance of these nanoparticles. Increasing the cut-off potential for discharging from 1.5 to $2.5 \mathrm{~V} v s$. Li/ $/ \mathrm{Li}^{+}$improved the cycle life of these $\mathrm{V}_{2} \mathrm{O}_{5}$ nanoparticles. Particles with the lowest specific surface area $\left(\sim 32 \mathrm{~m}^{2} \mathrm{~g}^{-1}\right)$ and highest phase purity (up to $98 \mathrm{wt} \%$ ) showed excellent cyclability between $2.5 \mathrm{and} 4.0 \mathrm{~V} v s$. Li/Li ${ }^{+}$, retaining a specific charge of $110 \mathrm{mAh} \mathrm{g}^{-1}$ beyond 100 cycles at a specific current of $100 \mathrm{~mA} \mathrm{~g}^{-1}$, and also superior specific charge of $100 \mathrm{mAh} \mathrm{g}^{-1}$ at specific current up to $20 \mathrm{C}$ rate (or $2000 \mathrm{~mA} \mathrm{~g}^{-1}$ ).
\end{abstract}

\section{Introduction}

Vanadium pentoxide or vanadia $\left(\mathrm{V}_{2} \mathrm{O}_{5}\right)$ is one of the few oxides having versatile redox-dependent properties due to the multiple valence state of vanadium, and therefore, finds wide applications in catalysis, ${ }_{-}^{1}$ electrochromism, ${ }_{-}^{2-4}$ and electrochemistry. ${ }_{-}^{5-7}$ Nanostructured forms of $\mathrm{V}_{2} \mathrm{O}_{5}$ have been employed in field-effect transistors (FETs), ${ }_{-}^{8}$ sensors, ${ }_{-}^{9-10}$ spintronic devices, ${ }_{-}^{11}$ and nanolithography templates. ${ }_{-1}^{12-13}$ In the field of rechargeable lithium batteries, besides low cost and abundant source, it is argued that $\mathrm{V}_{2} \mathrm{O}_{5}$ is an attractive cathode material owing to its unique features such as high electrochemical activity, high energy density, and high rate cyclability towards lithium insertion..$_{-}^{14}$ Electrochemical reduction of $\mathrm{V}_{2} \mathrm{O}_{5}$ can occur in a large potential window between 4.0 to $1.5 \mathrm{~V} v s$. $\mathrm{Li} / \mathrm{Li}^{+}$, where approximately three moles of lithium per mole of $\mathrm{V}_{2} \mathrm{O}_{5}$ could be theoretically inserted, leading to a theoretical specific charge of approximately $442 \mathrm{mAh} \mathrm{g}^{-1} \cdot-$

The reversible electrochemical lithium intercalation into $\mathrm{V}_{2} \mathrm{O}_{5}$ at room temperature was first reported by Whittingham in $1976 .{ }_{-}^{16}$ Depending on the amount of inserted lithium, several phase transitions of $\mathrm{Li}_{x} \mathrm{~V}_{2} \mathrm{O}_{5}$ in consecutive steps occur, namely $\alpha$ (for $x<0.01$ ), $\varepsilon(0.35<x<0.7$ ), and $\delta$ (for $x=1.0$ ) phases, respectively. ${ }^{17-18}$ For $x \leq 1$, the original $\mathrm{V}_{2} \mathrm{O}_{5}$ structure can be recovered upon lithium delithiation, and the phase transitions are fully reversible. ${ }_{-}^{19}$ However, as lithiation progresses $(x>1)$, a reconstruction occurs leading to a partially irreversible transformation from $\delta$-phase to $\gamma$-phase. ${ }_{-}^{17}$ This $\gamma$-phase can only be reversibly cycled in the stoichiometric range $0<x<2$ without changing the $\gamma$-type structure. ${ }^{17,20}$ Upon further lithiation (up to $x=3$ ), the $\gamma$-phase will be irreversibly transformed to the $\omega$-phase with a rock-salt type structure. The $\mathrm{Li}^{+}$ intercalation and deintercalation process can be expressed by the following overall equation: ${ }^{16-17}$

$$
\mathrm{V}_{2} \mathrm{O}_{5}+x \mathrm{Li}^{+}+x e^{-} \Leftrightarrow \mathrm{Li}_{x} \mathrm{~V}_{2} \mathrm{O}_{5}(0<x<3)
$$

In order to achieve a higher specific charge and better cyclability, extensive studies have been done on modifying the form and the structure of $\mathrm{V}_{2} \mathrm{O}_{5}$ as its electrochemical performance as $\mathrm{V}_{2} \mathrm{O}_{5}$ cathode depends on its degree of crystallinity and morphology. ${ }^{21-25}$ These studies showed that crystalline $\mathrm{V}_{2} \mathrm{O}_{5}$ has a high specific charge but has poor cycle life behaviour since its crystal structure is damaged by prolonged charge/discharge cycles. Meanwhile, amorphous and low crystallinity $\mathrm{V}_{2} \mathrm{O}_{5}$ allows faster lithium-ion diffusion and displays superior cyclability. Crystal deformation associated with lithiation may be relaxed in small crystallites with a high surface area that also leads to higher ionic conductivity. Therefore, nanocrystalline $\mathrm{V}_{2} \mathrm{O}_{5}$ has a promise as alternative cathode material in lithium batteries. ${ }^{24-25}$ 
Vanadia nanoparticles can be obtained by various physical and chemical techniques. Such powders have been prepared mostly by dry processes, such as vacuum evaporation, ${ }_{-26-27}$ and sputtering, ${ }_{-}^{28}$ although wet processes such as electrodeposition ${ }_{-}^{29}$ and sol-gel synthesis ${ }_{-}^{30}$ seem to be more advantageous in producing nanoparticles-based thin films on a large scale. Previously, we managed to obtain $\mathrm{V}_{2} \mathrm{O}_{5}$ nanoparticles by precipitation followed by heating in vacuum at $300{ }^{\circ} \mathrm{C} .{ }^{25,31}$ In addition, we also made $\mathrm{V}_{2} \mathrm{O}_{5}$ nanoparticles by flame spray pyrolysis (FSP) as secondary composite materials with the $\mathrm{TiO}_{2}$ and $\mathrm{SiO}_{2}$ for use in catalysis, ${ }_{-32}^{32}$ and even $\mathrm{FSP}-$ made $\mathrm{LiV}_{3} \mathrm{O}_{8}$ nanoparticles for lithium battery cathode materials. ${ }_{-}^{34} \mathrm{Here}$, crystalline $\mathrm{V}_{2} \mathrm{O}_{5}$ nanoparticles have been made by FSP to explore and evaluate their electrochemical performance for use as lithium battery cathodes focusing on the cut-off potential and the rate capability.

\section{Experimental}

\subsection{Material synthesis}

The experimental procedure for the FSP process is described in detail elsewhere. ${ }_{-}^{35}$ Here the precursor solution is prepared by first dissolving vanadium(V) oxytripropoxide (Aldrich, $98 \%$ ) into $30 \mathrm{~mL}$ of diethylene glycol (DEG, Fluka). This solution was then stirred into $30 \mathrm{~mL}$ of toluene (Riedel de Haen) and $20 \mathrm{~mL}$ of tetrahydrofuran (THF, Fluka). By varying the amount of vanadium(V) oxytripropoxide in the precursors, the vanadium molar precursor concentrations ranged from 0.4 to $1.5 \mathrm{M}$. The precursor solution was injected at 3 to $6 \mathrm{~mL} \mathrm{~min}^{-1}$ through the reactor nozzle and dispersed with $5.0 \mathrm{~L} \mathrm{~min}^{-1}$ of oxygen into a fine spray while maintaining a constant pressure drop of 1.5 bar across the nozzle tip. A premixed flame fueled by $1.3 \mathrm{~L} \mathrm{~min}^{-1}$ of methane and $3.0 \mathrm{~L} \mathrm{~min}^{-1}$ of oxygen was maintained to ignite and support the combustion of the spray. A sheath gas of $5.0 \mathrm{~L} \mathrm{~min}^{-1}$ of oxygen surrounding the flame was used to ensure complete combustion. The powder was collected by placing a glass fiber filter (GF/D Whatman, $257 \mathrm{~mm}$ in diameter) above the flame and drawing the gas streams with a vacuum pump. The reactor nozzle was cooled by water to prevent overheating and precursor evaporation within the liquid feed lines.

\subsection{Material characterization}

The powders were characterized by X-ray diffraction (XRD) using a Bruker AXS D8 Advance (40 kV, $40 \mathrm{~mA})$ diffractometer and analyzed with the Topas 2 software. The XRD measurement was performed at a continuous scan between $2 \theta$ angles of 10 and $70^{\circ}$ at a scan rate of $0.03^{\circ} \mathrm{min}^{-1}$. Analysis by field-emission scanning electron microscopy (FE-SEM) was performed with a Zeiss Gemini 1530 operated at $1 \mathrm{kV}$. For the investigation by transmission electron microscopy (TEM), the material was deposited onto a holey carbon foil supported on a copper grid. TEM investigations were performed using a CM30ST microscope (Philips; $\mathrm{LaB}_{6}$ cathode, operated at $300 \mathrm{kV}$, point resolution $\sim 2 \AA$ ). The BrunauerEmmett-Teller specific surface area $\left(S_{\mathrm{BET}}\right)$ of the FSP-produced nanoparticles was determined through a five-point nitrogen adsorption isotherm at $77 \mathrm{~K}$ (Tristar, Micrometrics Instruments Corp.) after degassing the powder samples with nitrogen at $150{ }^{\circ} \mathrm{C}$. Assuming spherical, monodisperse primary particles with homogeneous density, the average particle size $\left(D_{\mathrm{BET}}\right)$ in microns is equaled to $6 /\left(S_{\mathrm{BET}} * \rho_{\mathrm{av}}\right)$, where $\rho_{\mathrm{av}}$ is the average density of the flame-made $\mathrm{VO}_{x}$ (based on the mass fractions of $\mathrm{V}_{2} \mathrm{O}_{5}$ and $\mathrm{VO}_{2}$, respectively) nanoparticles with $\rho_{\mathrm{V}_{2} \mathrm{O}_{5}}=3.4 \mathrm{~g} \mathrm{~cm}^{-3}$ and $\rho_{\mathrm{VO}_{2}}=4.7 \mathrm{~g} \mathrm{~cm}^{-3}$.

\subsection{Electrode preparation and cell assembly}

The cathode was prepared by mixing FSP-made nanocrystalline $\mathrm{V}_{2} \mathrm{O}_{5}$ or commercially available micro-sized $\mathrm{V}_{2} \mathrm{O}_{5}$ particles (Sigma-Aldrich) as electroactive materials with $20 \mathrm{wt} \%$ carbon black (Super P, TIMCAL, Belgium) and $10 \mathrm{wt} \%$ polyvinylidene fluoride (PVDF, Sigma-Aldrich) binder in N-methyl-2-pyrrolidinone (NMP, Merck GmbH) solvent to form a viscous slurry. Subsequently, the slurry was doctor-bladed at a thickness of $200 \mu \mathrm{m}$ onto an aluminum foil and dried under vacuum at $110^{\circ} \mathrm{C}$ overnight. Circular electrodes with a diameter of $13 \mathrm{~mm}$ were punched out and dried in a vacuum chamber at $120^{\circ} \mathrm{C}$ overnight, each with a typical active material mass loading of $2-3 \mathrm{mg} \mathrm{cm}^{-2}$. Hermetically sealed laboratory test cells ${ }_{-}^{36}$ were used in which the working and counter electrodes (metallic lithium, Aldrich, 99.9\%) were slightly pressed together (at $2 \mathrm{~kg} \mathrm{~cm}^{-2}$ ) against a glass fiber separator soaked with $500 \mu \mathrm{L}$ of standard battery electrolyte [1 M LiPF6 in ethylene carbonate (EC)/dimethyl carbonate (DMC) (1/1 by weight), provided by Ferro GmbH] Test cells were assembled in an argon-filled glove box with oxygen and water content each less than $1 \mathrm{ppm}$.

\subsection{Electrochemical measurements}

Both the cyclic voltammetry (CV) and galvanostatic measurements were performed by a computer-controlled cell capture (CCCC) system (Astrol Electronics AG, Oberrohrdorf, Switzerland), by discharging ( $\mathrm{Li}^{+}$insertion) first from the respective open-circuit potential. The $\mathrm{CV}$ was conducted between 1.5-4.0 V vs. $\mathrm{Li} / \mathrm{Li}^{+}$at a potential scan rate of $0.1 \mathrm{mV} \mathrm{s}^{-1}$. Meanwhile, for the galvanostatic measurements electrodes were cycled between 1.5-4.0 V vs. Li/ $\mathrm{Li}^{+}$at specific currents ranging from 100 to $2000 \mathrm{~mA} \mathrm{~g}^{-1}$ (based on the oxide weight). In order to promote complete discharge/charge at the respective potential limits, a potentiostatic step was included until the current was $10 \%$ of the current used in the galvanostatic step.

\section{Results and discussion}


The processing conditions for the FSP were varied in order to investigate and optimize the physical properties of the flame spray pyrolyzed $\mathrm{V}_{2} \mathrm{O}_{5}$ nanoparticles, such as degree of crystallinity, average particle size $\left(D_{\mathrm{BET}}\right)$ and morphology, and final composition. The physical characteristics of 6 different $\mathrm{V}_{2} \mathrm{O}_{5}$ nanoparticles samples are summarized in Table 1 .

Table 1 FSP operating conditions and the corresponding physical properties of the $\mathrm{V}_{2} \mathrm{O}_{5}$ nanoparticles produced

\begin{tabular}{|c|c|c|c|c|c|c|c|c|}
\hline \multirow[b]{2}{*}{ Sample } & \multirow[b]{2}{*}{$C_{\mathrm{F}} \stackrel{\underline{a}}{/} / \mathbf{M}$} & \multirow[b]{2}{*}{$Q_{F} \stackrel{b}{m} / \mathrm{mL} \mathrm{min}^{-1}$} & \multirow[b]{2}{*}{$S_{\mathrm{BET}}{ }^{c} / \mathbf{m}^{2} \mathbf{g}^{-1}$} & \multirow[b]{2}{*}{$D_{\mathrm{BET}} \stackrel{d}{/ n m}$} & \multicolumn{2}{|c|}{ Composition $/$ wt $\%$} & \multicolumn{2}{|c|}{$D_{\mathrm{XRD}} f / \mathrm{nm}$} \\
\hline & & & & & $\mathrm{V}_{2} \mathrm{O}_{5}$ & $\mathrm{VO}_{2}$ & $\mathrm{~V}_{2} \mathrm{O}_{5}$ & $\mathrm{VO}_{2}$ \\
\hline FSP-1 & 0.40 & 5 & 60.5 & 29 & 87.6 & 12.4 & 28 & 31 \\
\hline FSP-2 & 0.75 & 5 & 46.1 & 39 & 97.5 & 2.5 & 24 & 34 \\
\hline FSP-3 & 1.50 & 5 & 40.7 & 44 & 97.6 & 2.4 & 23 & 35 \\
\hline FSP-4 & 1.50 & 3 & 53.3 & 33 & 93.4 & 6.6 & 28 & 32 \\
\hline FSP-5 & 1.50 & 4 & 44.3 & 41 & 97.5 & 2.5 & 20 & 41 \\
\hline FSP-6 & 1.50 & 6 & 31.9 & 56 & 97.8 & 2.2 & 26 & 39 \\
\hline Aldrich & $\mathrm{N} / \mathrm{A}$ & $\mathrm{N} / \mathrm{A}$ & 4.1 & 440 & 100.0 & 0.0 & $>100$ & $\mathrm{~N} / \mathrm{A}$ \\
\hline
\end{tabular}

As can be seen from Table 1, the increase in feed precursor's molar concentration $\left(C_{\mathrm{F}}\right)$ from 0.4 to $0.75 \mathrm{M}$ (at constant feed injection rate, $Q_{\mathrm{F}}$ ) resulted in an increase in $\mathrm{V}_{2} \mathrm{O}_{5}$ content from 87.6 to $97.5 \mathrm{wt} \%$. Further increase of $C_{\mathrm{F}}$ to $1.50 \mathrm{M}$ increased the $\mathrm{V}_{2} \mathrm{O}_{5}$ content only marginally $(0.1$ $\mathrm{wt} \%$ ). This is consistent with Schimmoeller et al..$_{-}^{37}$ who also observed increased $\mathrm{V}_{2} \mathrm{O}_{5}$ content with increasing V-concentration in the precursor solution in their FSP-made $\mathrm{V}_{2} \mathrm{O}_{5}-\mathrm{TiO}_{2}$ particles. For FSP-1, the particle size $\left(D_{\mathrm{BET}}\right)$ is roughly equal to the crystal size $\left(D_{\mathrm{XRD}}\right)$, indicating that the powder is composed of monocrystalline particles. For FSP-2 and FSP-3, $D_{\mathrm{BET}}$ increases and $D_{\mathrm{XRD}}$ slightly decreases for increasing $C_{\mathrm{F}}$, suggesting these particles are composed of multiple crystals and are therefore polycrystalline. When $Q_{\mathrm{F}}$ was increased from 3 to $6 \mathrm{~mL} \mathrm{~min}^{-1}$ at a $C_{\mathrm{F}}$ of $1.5 \mathrm{M}$, polycrystallinity was increased further (caused by vanishing of the detected $\mathrm{VO}_{2}$ phase) ) $_{-}^{37}$ as the $S_{\text {BET }}$ was reduced even more to $31.9 \mathrm{~m}^{2} \mathrm{~g}^{-1}$ without significantly increasing the crystal size $\left(D_{\mathrm{XRD}} \approx 28 \mathrm{~nm}\right.$ ). The reduction of $S_{\mathrm{BET}}$ from $53.3 \mathrm{~m}^{2} \mathrm{~g}^{-1}$ (FSP-4) to $31.9 \mathrm{~m}^{2} \mathrm{~g}^{-1}$ (FSP-6) corresponds to the growth of the particles with a $D_{\mathrm{BET}}$ from $33 \mathrm{~nm}$ (FSP-4) to $56 \mathrm{~nm}$ (FSP-6). As seen from the difference in particle $\left(D_{\mathrm{BET}}\right)$ and crystal size $\left(D_{\mathrm{XRD}}\right)$ at higher $Q_{\mathrm{F}}$ rates, particles are sintered rather than coagulated. This observation is consistent with the effect of precursor concentration in $\mathrm{TiO}_{2}$ produced by flame synthesis. ${ }_{-}^{38}$ These properties will be beneficial from the electrochemistry point of view since smaller crystals lead to faster solid-state diffusion kinetics. The higher specific surface area $\left(\mathrm{m}^{2} \mathrm{~g}^{-1}\right)$ of the smaller crystals permits more Li ions to be transferred per unit time from the electrolyte to the nanoparticles for the same mass of electroactive material. Meanwhile lower surface area will provide less unwanted surface reactions such as dissolution of the active transition metal and the irreversible charge loss from surface film formation during the first charge.

Typical XRD patterns for the 6 different $\mathrm{V}_{2} \mathrm{O}_{5}$ nanoparticles powder samples produced by $\mathrm{FSP}$ and for the commercially available $\mathrm{V}_{2} \mathrm{O}_{5}$ micro-sized particles are shown in Fig. 1. Most of the peak positions for the flame spray pyrolyzed $\mathrm{V}_{2} \mathrm{O}_{5}$ nanoparticles agree well with those of the orthorhombic $\mathrm{V}_{2} \mathrm{O}_{5}$ (JCPDS 41-1426; $a=11.5160 \AA, b=3.5656 \AA$, and $c=4.3727 \AA$ ), except for the 2 peaks marked as “@” and “\#” which correspond to the (110) and (011) peaks from the monoclinic $\mathrm{VO}_{2}$ (JCPDS 43-1051) impurities present, as observed also by Schimmoeller et al. . $_{-}^{37}$ Moreover, based on the fundamental parameter approach and the Rietveld method, ${ }_{-}^{39} D_{\text {XRD }}$ ranging from 20 to 28 nm was estimated from peak (001) of the $\mathrm{V}_{2} \mathrm{O}_{5}$ phase (see Fig. 1a-f, also listed in Table 1). Note that Table 1 shows that the present flame-made $\mathrm{V}_{2} \mathrm{O}_{5}$ nanoparticles had high $S_{\text {BET }}\left(32-61 \mathrm{~m}^{2} \mathrm{~g}^{-1}\right)$ which is an order of magnitude higher than that of the commercially available $\mathrm{V}_{2} \mathrm{O}_{5}\left(\sim 4 \mathrm{~m}^{2} \mathrm{~g}^{-1}\right)$. 


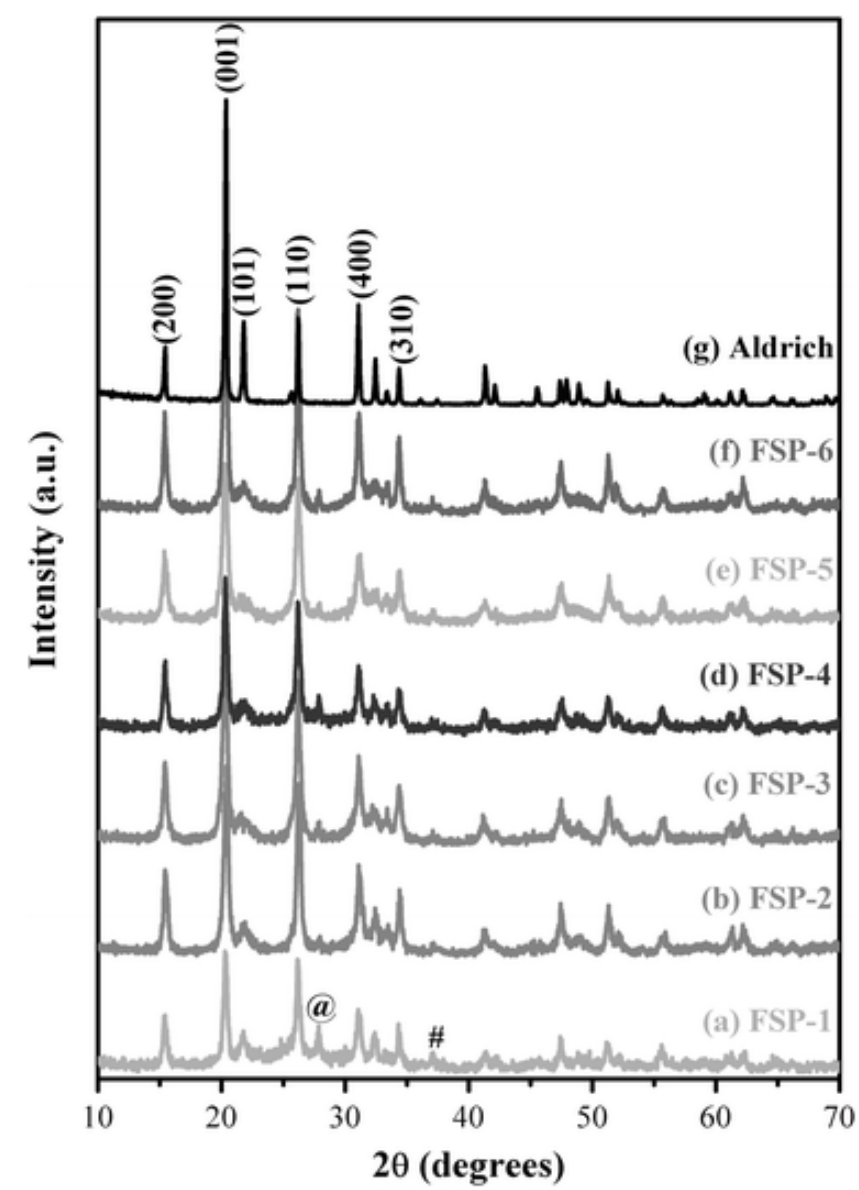

Fig. 1 X-Ray diffraction (XRD) patterns of FSP-made $\mathrm{V}_{2} \mathrm{O}_{5}$ nanoparticles (a)-(f) and $\mathrm{V}_{2} \mathrm{O}_{5}$ microparticles from Aldrich (g). The impurities phase $\mathrm{VO}_{2}$ is indicated as “@” (110) and “\#” (011).

Fig. 2 shows a typical field emission scanning electron microscope (FE-SEM) images of the flame spray pyrolyzed $\mathrm{V}_{2} \mathrm{O}_{5}$ nanoparticles, which is sample FSP-6 in this case. In the low-magnification image (Fig. 2a), sphere-like $\mathrm{V}_{2} \mathrm{O}_{5}$ nanoparticles are seen with a fairly homogeneous particle size distribution. In the high-magnification image (Fig. 2b), flame-made $\mathrm{V}_{2} \mathrm{O}_{5}$ nanoparticles are seen with diameters ranging from 30-60 nm. This is in good agreement with the calculations of $D_{\mathrm{XRD}}$, which is the average size of the $\mathrm{V}_{2} \mathrm{O}_{5}$ crystals based on the weight fraction of the $\mathrm{V}_{2} \mathrm{O}_{5}$ phase. However, as seen in Fig. 2b, the majority of particles are approximately $30 \mathrm{~nm}$ in diameter, and therefore in the same size range of those estimated from the XRD patterns in Fig. 1. 


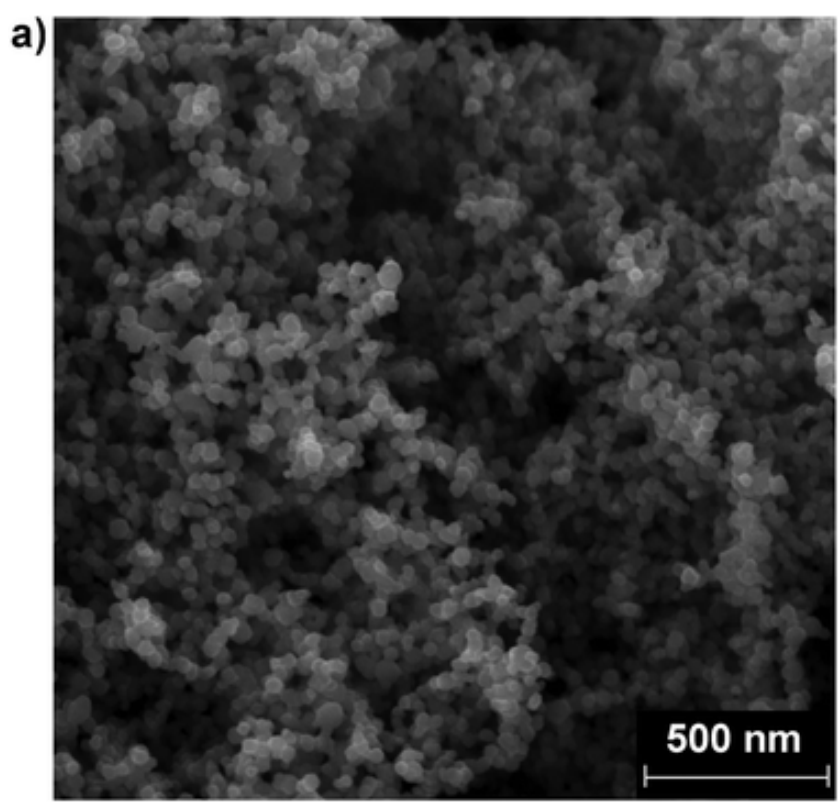

b)

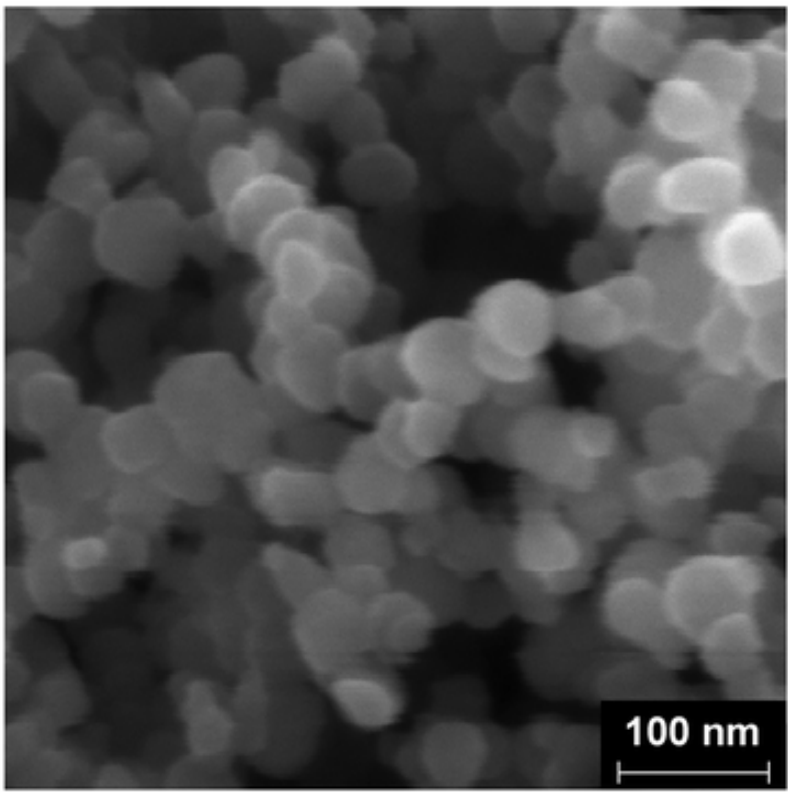

Fig. 2 FE-SEM images of $\mathrm{V}_{2} \mathrm{O}_{5}$ nanoparticles (here FSP-6) at (a) low and (b) high magnifications. The spherical-shaped particles are almost monodisperse with sizes ranging from $30-60 \mathrm{~nm}$.

Fig. 3a and $3 \mathrm{~b}$ show typical transmission electron microscope (TEM) images of the present $\mathrm{V}_{2} \mathrm{O}_{5}$ nanoparticles indicating that the sphere-like $\mathrm{V}_{2} \mathrm{O}_{5}$ primary particles are connected to each other by sintered necks to form chain-like aggregates, seen in related work on $\mathrm{LiV}_{3} \mathrm{O}_{8}{ }_{-}^{34} \mathrm{Furthermore}$ from the high-resolution TEM image in Fig. 3(c), the crystalline structure of the flame-made $\mathrm{V}_{2} \mathrm{O}_{5}$ nanoparticles is evidenced by their clearly visible lattice fringes. The measured distance of $c a$. $0.652 \mathrm{~nm}$ corresponds to half of the $a$-axis. The corresponding selected area electron diffraction (SAED) pattern for the $\mathrm{V}_{2} \mathrm{O}_{5}$ nanoparticles in Fig. $3 \mathrm{~b}$ is shown in Fig. 3d, revealing the crystal lattice parameter of the $\mathrm{V}_{2} \mathrm{O}_{5}$ nanoparticles, in accord with the orthorhombic phase of $\mathrm{V}_{2} \mathrm{O}_{5}$ (JCPDS 41-1426). 
a)

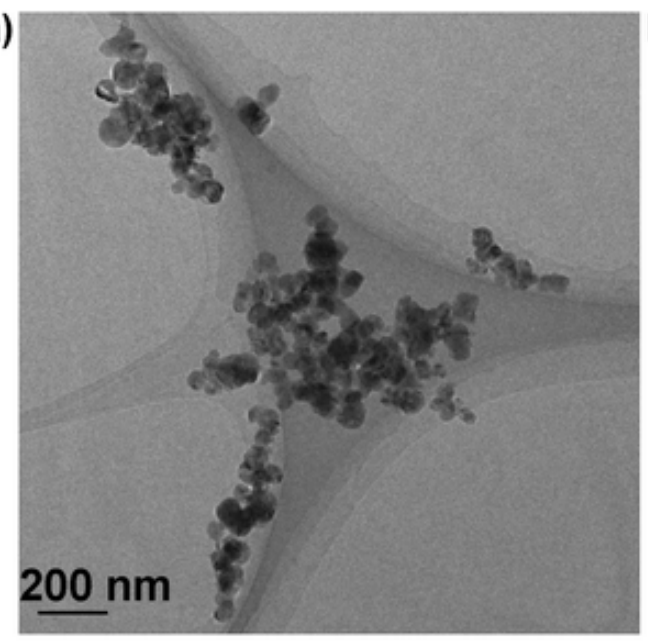

c)

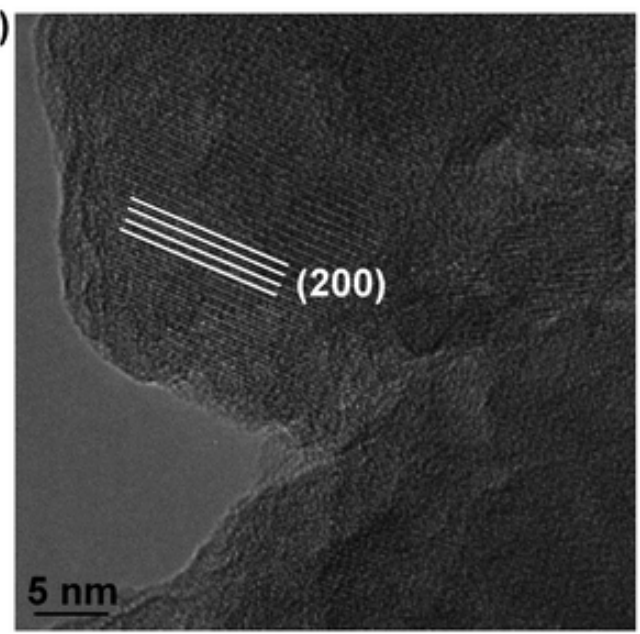

b)

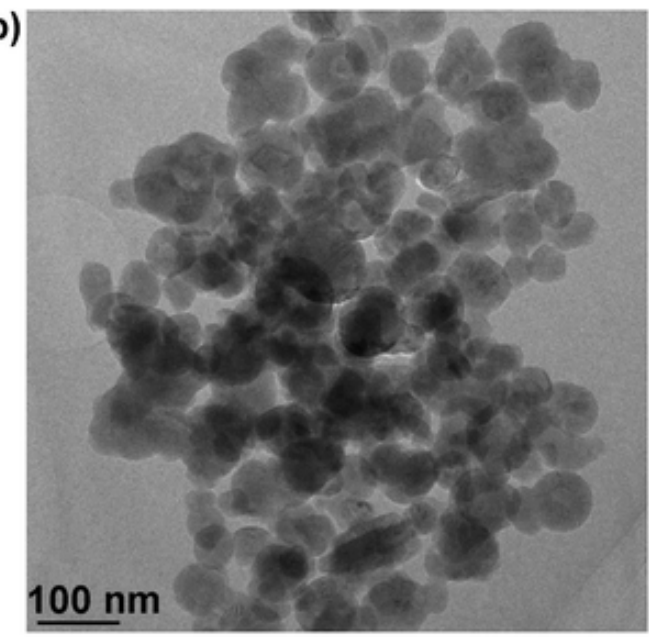

d)

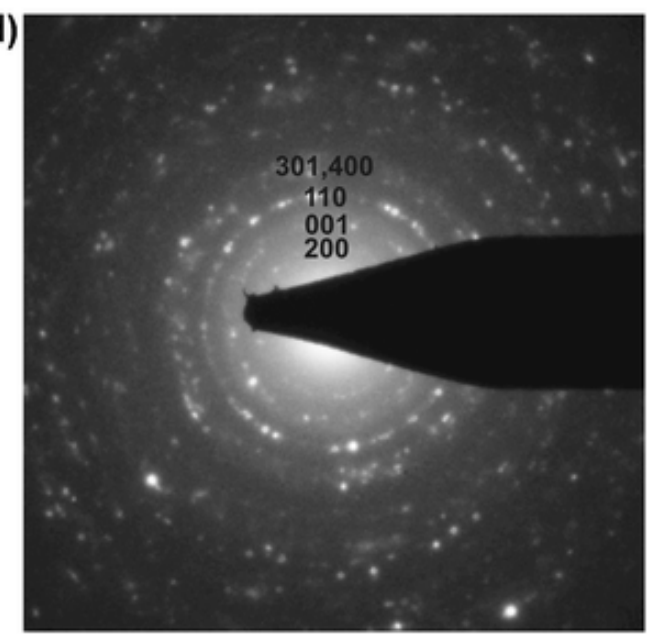

Fig. 3 TEM images of FSP-made $\mathrm{V}_{2} \mathrm{O}_{5}$ nanoparticles (here FSP-6): (a) and (b) are overview images, showing nanoparticles connected by sinter necks forming chain-like aggregates; (c) high-resolution TEM image highlighting the (200) lattice planes; and (d) the selected area electron diffraction (SAED) pattern taken from image (b).

\subsection{Electrochemical performance of $\mathrm{V}_{2} \mathrm{O}_{5}$ nanoparticles}

Fig. $4 \mathrm{a}-\mathrm{c}$ show the cyclic voltammograms (CVs) of electrodes made from the FSP- $6 \mathrm{~V}_{2} \mathrm{O}_{5}$ nanoparticles. The CVs were taken at a scan rate of 0.1 $\mathrm{mV} \mathrm{s}^{-1}$ with cycling at different lower (discharge) cut-off potentials. From Fig. 4a, it can be seen that during the cathodic scanning in the first cycle, four distinctive peaks are observed at $3.35,3.15,2.26$, and $1.87 \mathrm{~V} v$ s. $\mathrm{Li} / \mathrm{Li}^{+}$, which corresponds to a complex multi-step lithium intercalation process. ${ }_{-}^{17}$ As lithium ions are inserted into the layers of $\mathrm{V}_{2} \mathrm{O}_{5}$, the phase transformation occurs consecutively from $\alpha-\mathrm{V}_{2} \mathrm{O}_{5}$ to $\varepsilon-\mathrm{Li}_{0.5} \mathrm{~V}_{2} \mathrm{O}_{5}(3.35 \mathrm{~V}), \delta-\mathrm{LiV}_{2} \mathrm{O}_{5}(3.15 \mathrm{~V}), \gamma-\mathrm{Li}_{2} \mathrm{~V}_{2} \mathrm{O}_{5}(2.26 \mathrm{~V})$, and $\omega-\mathrm{Li}_{3} \mathrm{~V}_{2} \mathrm{O}_{5}(1.87 \mathrm{~V}) . \stackrel{19,20,40}{ }$ Among the various phases of $\mathrm{Li}_{x} \mathrm{~V}_{2} \mathrm{O}_{5}, \delta-\mathrm{LiV}_{2} \mathrm{O}_{5}$ can be restored to pristine $\mathrm{V}_{2} \mathrm{O}_{5}$ through lithium deintercalation, while $\gamma-\mathrm{Li}_{2} \mathrm{~V}_{2} \mathrm{O}_{5}$ and $\omega_{3}-\mathrm{Li}_{2} \mathrm{~V}_{2} \mathrm{O}_{5}$ (rock-salt type structure) are formed irreversibly. In the following anodic scanning, two broad peaks were observed at around 2.67 and $3.26 \mathrm{~V} v s$. $\mathrm{Li} / \mathrm{Li}^{+}$, respectively, corresponding to the lithium extraction processes..$^{24,25}$ 

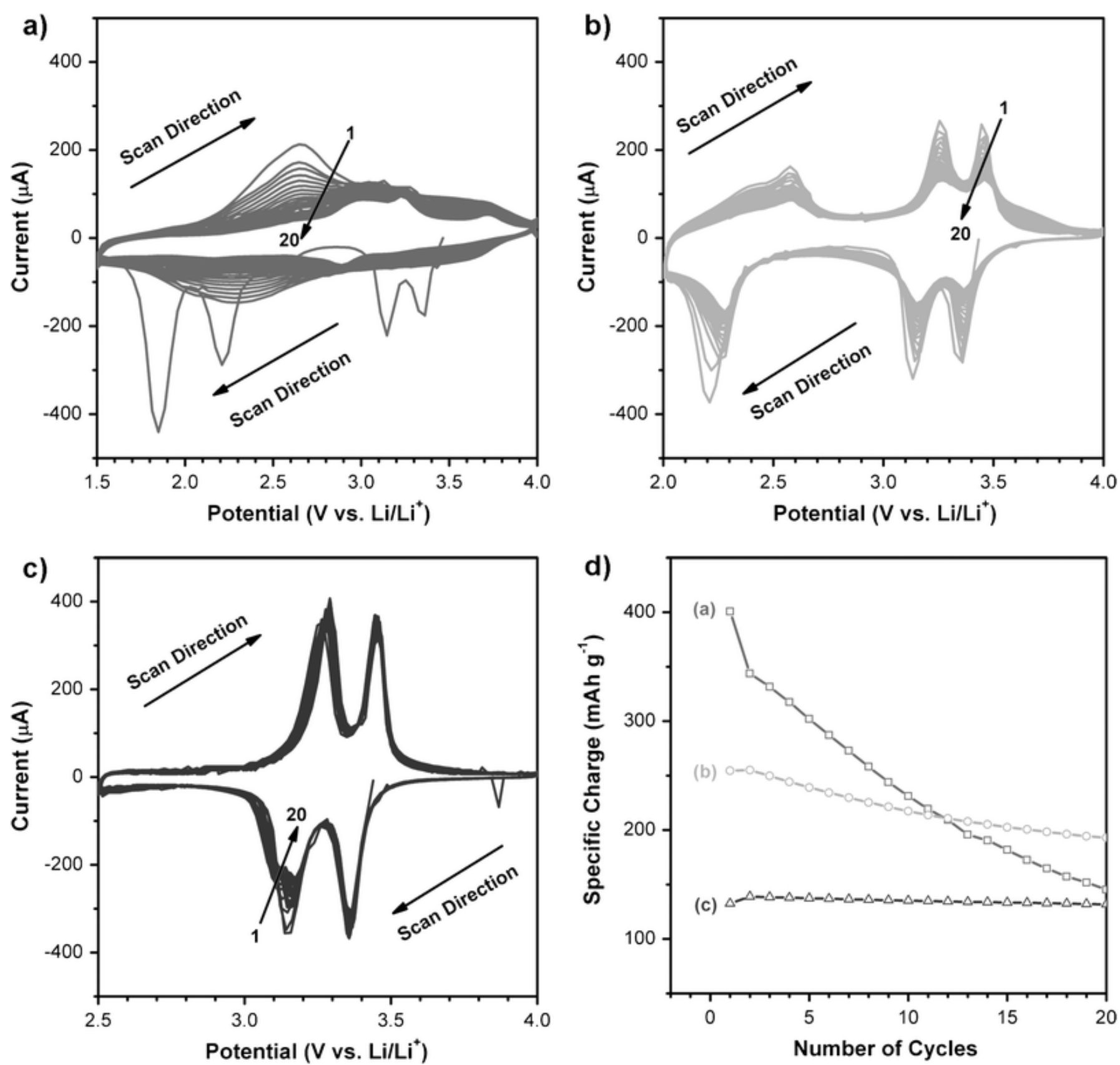

Fig. 4 Cyclic voltammograms (CVs) of the first 20 cycles of nanostructured $\mathrm{V}_{2} \mathrm{O}_{5}$ particles (here FSP-6) at different lower cut-off potentials $v s$. $\mathrm{Li} / \mathrm{Li}^{+}$: (a) $1.5 \mathrm{~V}$, (b) $2.0 \mathrm{~V}$, and (c) $2.5 \mathrm{~V}$, at a scan rate of $0.1 \mathrm{mV} \mathrm{s}^{-1}$. (d) Specific charge $v s$. cycle number from the CVs in plot (a) to (c).

From Fig. $4 \mathrm{~b}$ and $\mathrm{c}$, it can be seen that the reversibility of the redox kinetics with cycling improves when the discharge cut-off potential is limited to $2.5 \mathrm{~V} v s$. $\mathrm{Li} / \mathrm{Li}^{+}$. This can be explained by the fact that the $\delta-\mathrm{LiV}_{2} \mathrm{O}_{5}$ phase can be reversibly cycled without destroying the crystal structure of the $\mathrm{V}_{2} \mathrm{O}_{5}$ nanoparticles. ${ }_{-}^{17}$ In addition, Fig. 4d shows the corresponding specific charge from the CV curves in Fig. 4a to c for the first 20 cycles. It revealed that the charge fading increases with a larger cycling potential window. Therefore, it is essential to investigate the effect of the discharge cut-off potentials.

After prolonged galvanostatic cycling at 100 cycles, it was found that the FSP-6 $\mathrm{V}_{2} \mathrm{O}_{5}$ electrode with a discharge cut-off potential of $2.5 \mathrm{~V} v s$. $\mathrm{Li} / \mathrm{Li}^{+}$retained the highest specific charge of approximately $110 \mathrm{mAh} \mathrm{g}^{-1}$, when cycled at a specific current of $100 \mathrm{~mA} \mathrm{~g}^{-1}(\underline{\text { Fig. }})$. 


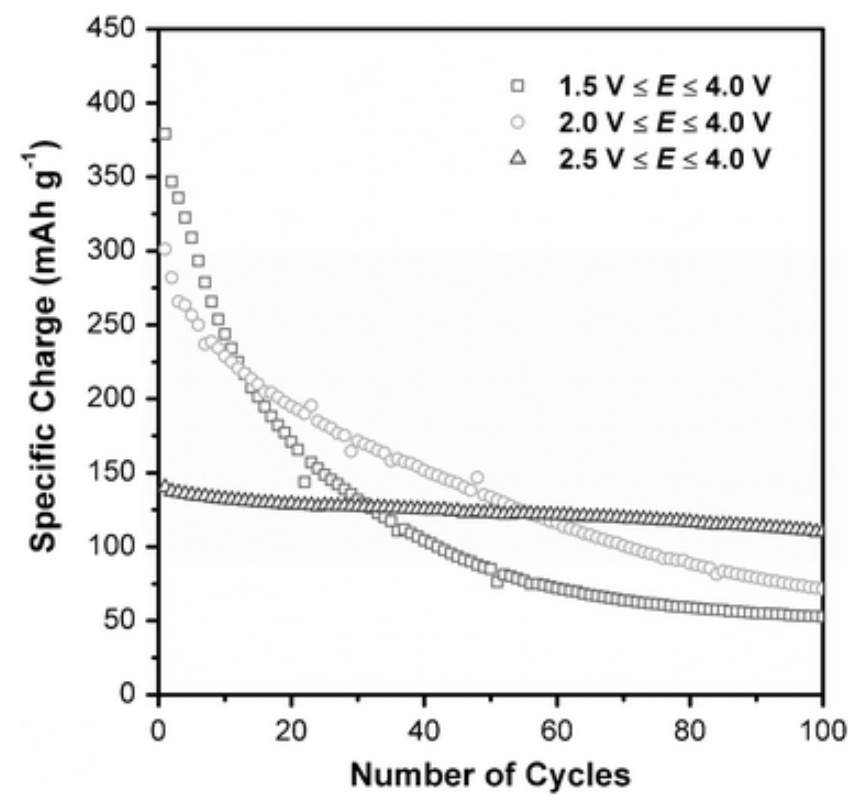

Fig. 5 Galvanostatic cycling behaviour of the nanostructured $\mathrm{V}_{2} \mathrm{O}_{5}$ electrodes (here FSP-6) at lower cut-off potential $v s . \mathrm{Li} / \mathrm{Li}^{+}$of $1.5 \mathrm{~V}$, $2.0 \mathrm{~V}$, and $2.5 \mathrm{~V}$, respectively. The specific current was $100 \mathrm{~mA} \mathrm{~g}^{-1}$.

From the point of view of the entire battery, it is beneficial and practical to limit the cycling potential window of the positive electrode to $2.5 \mathrm{~V}$ $v s$. $\mathrm{Li} / \mathrm{Li}^{+}$; the electrochemical performance of the 6 different $\mathrm{V}_{2} \mathrm{O}_{5}$ nanoparticle electrodes were compared accordingly. As can be seen from Fig. 6 , the initial specific charge of all $\mathrm{V}_{2} \mathrm{O}_{5}$ electrodes, represented by the patterned columns, were above $140 \mathrm{mAh} \mathrm{g}^{-1}$, except for samples FSP-1 and FSP-4. These high initial specific charge values are almost that of the theoretical value (148 $\left.\mathrm{mAh} \mathrm{g}^{-1}\right)$ and show that these nanoparticle-based electrodes are cycling well. In fact, one reason for the lower initial specific charge of the samples FSP-1 and FSP-4 is the higher wt $\%$ of $\mathrm{VO}_{2}$ impurities in these samples, as shown in Table 1. However, when comparing the specific charge retained after 100 cycles, represented by the solid columns in Fig. 6, sample FSP-6 was clearly superior, retaining a specific charge of approximately $110 \mathrm{mAh} \mathrm{g}^{-1}$, which was almost $80 \%$ of its initial charge. This excellent cycling behaviour could be due to the lower amount of surface reactions (vanadium dissolutions, passivation film formation, etc.) as sample FSP-6 has the lowest $S_{\mathrm{BET}}$ of $32 \mathrm{~m}^{2} \mathrm{~g}^{-1}$.

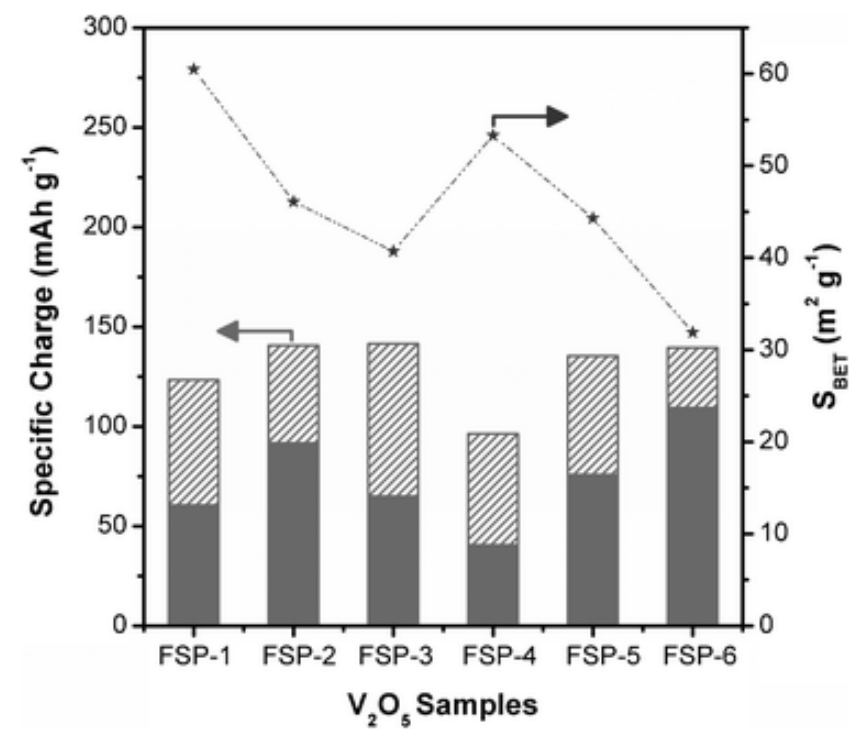

Fig. 6 Specific surface area $\left(S_{\mathrm{BET}}\right)$ and electrochemical performance of 6 different $\mathrm{FSP}$-made $\mathrm{V}_{2} \mathrm{O}_{5}$ electrodes, galvanostatically cycled between 2.5 and $4.0 \mathrm{~V} v$ s. $\mathrm{Li} / \mathrm{Li}^{+}$at $100 \mathrm{~mA} \mathrm{~g}^{-1}$. The patterned columns represent the specific charge for the first cycle, while the solid columns indicate the specific charge remaining after 100 cycles.

Although a lower specific surface area is beneficial in reducing the side reactions during the electrochemical cycling, use of larger microparticles should not necessarily be the direction of future research. This is because nanosized particles have improved rate capability and, thus, the practical energy density at higher currents. Clearly there is a trade-off between the high rate capability of nanoparticles and the reduced 
amount of detrimental side reactions between microparticles and the electrolyte. To investigate the effect of $\mathrm{V}_{2} \mathrm{O}_{5}$ particle size further, the electrochemical performances of the FSP-6 (nanoparticles) and the Aldrich (microparticles) electrodes are compared (see Fig. 7). Cycling was performed between 2.5 and $4.0 \mathrm{~V} v$ s. $\mathrm{Li} / \mathrm{Li}^{+}$. As can be seen from Fig. 7a, when cycled at a low specific current of $100 \mathrm{~mA} \mathrm{~g}^{-1}$ beyond 100 cycles, the nanostructured FSP-6 electrode retained a higher specific charge of $110 \mathrm{mAh} \mathrm{g}^{-1}$ compared to $88 \mathrm{mAh} \mathrm{g}^{-1}$ for the microstructured Aldrich oxide-based electrode. The power performance of battery electrodes depends on the size of the particles, making up the electrodes, and on the electrode surface area. As can be seen from Fig. 7b, the FSP-6 nanostructured electrodes have better rate capabilities when compared to the microstructured Aldrich oxide-based electrode, even up to the $20 \mathrm{C}$ rate (corresponding to $2000 \mathrm{~mA} \mathrm{~g}^{-1}$ ), retaining a specific charge above 100 $\mathrm{mAh} \mathrm{g}^{-1}$. This is obviously due to the shorter $\mathrm{Li}^{+}$diffusion path lengths in the nanoparticles when compared to the microparticles. This effect delays the significant influence of the concentration polarization in the solid state to higher discharge currents, resulting in better rate capabilities and higher specific charge at high discharge rates. ${ }^{21,25}$
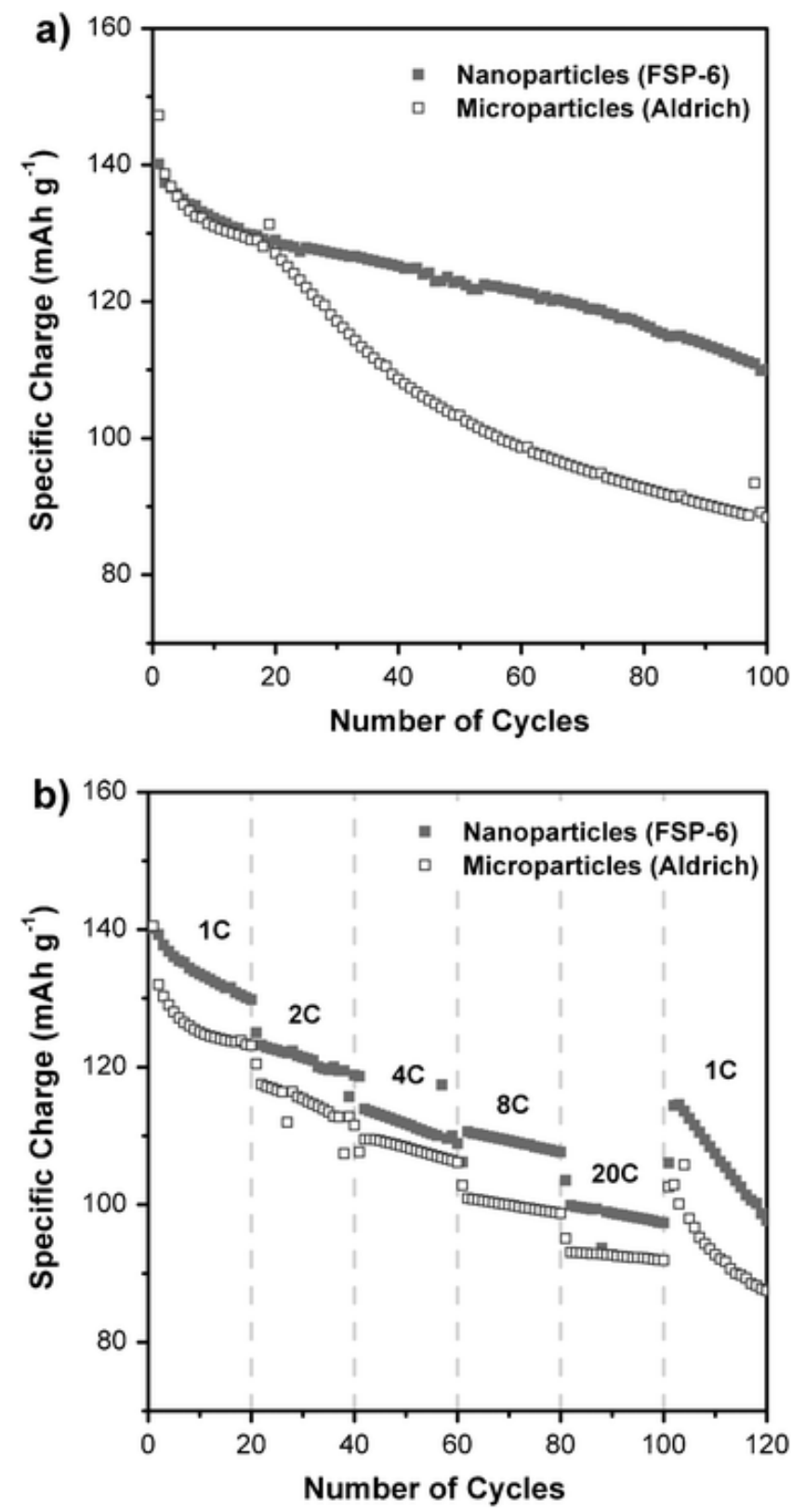

Fig. 7 Galvanostatic cycling behaviour of $\mathrm{V}_{2} \mathrm{O}_{5}$ electrodes for nanoparticles (here FSP-6) and for microparticles (Aldrich): (a) cycling at a specific current of $100 \mathrm{~mA} \mathrm{~g}^{-1}$, and (b) consecutive cycling at different specific currents. Electrodes were cycled between 2.5 and 4.0 $\mathrm{V}$ versus $\mathrm{Li} / \mathrm{Li}^{+}$. Here $1 \mathrm{C}$-rate is set to $100 \mathrm{~mA} \mathrm{~g}^{-1}$.

\section{Conclusions}

In this study, we have successfully synthesized crystalline, spherical-like $\mathrm{V}_{2} \mathrm{O}_{5}$ nanoparticles by flame spray pyrolysis and optimized the process 
conditions to obtain nanoparticles with improved electrochemical performance. Both the XRD patterns and SEM images revealed crystalline particles of approximately $30-60 \mathrm{~nm}$ in diameter. When the precursor's concentration and injection rate were increased, higher $\mathrm{V}_{2} \mathrm{O}_{5}$ crystal purity (up to $98 \mathrm{wt} \%$ ) and bigger particles with lower surface area $\left(\sim 32 \mathrm{~m}^{2} \mathrm{~g}^{-1}\right)$ were made. In addition, it was found that the $\mathrm{V}_{2} \mathrm{O}_{5}$ nanostructures showed an improved cycling behaviour when the lower cut-off potential (for discharging) is increased from 1.5 to $2.5 \mathrm{~V} v s$. $\mathrm{Li} / \mathrm{Li}^{+}$. The significant charge "loss" when discharging to $1.5 \mathrm{~V} v s . \mathrm{Li} / \mathrm{Li}^{+}$is most probably related to the structural changes upon cycling in the larger potential span. Flame-made $\mathrm{V}_{2} \mathrm{O}_{5}$ nanoparticles with the lowest specific surface area and the highest purity show excellent cyclability when cycled between 2.5 and $4.0 \mathrm{~V} v \mathrm{~s} . \mathrm{Li} / \mathrm{Li}^{+}$, retaining a specific charge of $110 \mathrm{mAh} \mathrm{g}^{-1}$ beyond 100 cycles at a specific current of $100 \mathrm{~mA} \mathrm{~g}^{-1}$, and also a superior specific charge of $100 \mathrm{mAh} \mathrm{g}^{-1}$ at a specific current up to $20 \mathrm{C}$ rate (or $2000 \mathrm{~mA} \mathrm{~g}^{-1}$ ).

\section{Acknowledgements}

Scientific discussions with Prof. Alexander Wokaun (PSI and ETH Zurich), Dr Jean-François Colin (PSI), and B. Schimmoeller (ETH Zurich) are gratefully acknowledged. This research was partially supported by ETH Research Grants TH-29/05-2 and TH-09/06-2. S.-H. Ng thanks the ARC Centre of Excellence funding under the grant number CE0561616, for providing financial support during his PhD studies at the University of Wollongong, Australia. We thank the Electron Microscopy Center of the ETH Zurich (EMEZ) for providing the necessary infrastructure.

\section{References}

1. C. Karunakaran and S. Senthilvelan, J. Colloid Interface Sci., 2005, 289, 466-471 CrossRef CAS Search PubMed Find@uowO

2. C. Sanchez, R. Morineau and J. Livage, Phys. Status Solidi A, 1983, 76, 661-666 CrossRef CAS Search PubMed Find@uow:

3. A. R. Raju and C. N. R. Rao, J. Chem. Soc., Chem. Commun., 1991, 18, 1260-1261 Search PubMed Find@uow).

4. C. Imawan, H. Steffes, F. Solzbacher and F. Obermeier, Sens. Actuators, B, 2001, 77, 346-351 CrossRef Search PubMed Find@uowo

5. G. R. Goward, F. Leroux and L. F. Nazar, Electrochim. Acta, 1998, 43, 1307-1313 CrossRef CAS Search PubMed Find@uow:

6. M. Lira-Cantú and P. Gómez-Romero, J. Electrochem. Soc., 1999, 146, 2029-2033 CrossRef CAS Search PubMed Find@uow.

7. E. Shouji and D. A. Buttry, Electrochim. Acta, 2000, 45, 3757-3764 CrossRef CAS Search PubMed Find@uow.

8. J. Muster, G. T. Kim, V. Krstić, J. G. Park, Y. W. Park, S. Roth and M. Burghard, Adv. Mater., 2000, 12, 420-424 CrossRef CAS Search PubMed FIND@Uow.

9. J. Livage, Chem. Mater., 1991, 3, 578-593 CrossRef CAS Search PubMed Find@uow:

10. J. Liu, X. Wang, Q. Peng and Y. Li, Adv. Mater., 2005, 17, 764-767 CrossRef CAS Search PubMed Find@uowor.

11. L. Krusin-Elbaum, D. M. Newns, H. Zeng, V. Derycke, J. Z. Sun and R. Sandstrom, Nature, 2004, 431, 672-676 CrossRef CAS Search PubMed Find@uow

12. R. Söordan, M. Burghard and K. Kern, Appl. Phys. Lett., 2001, 79, 2073-2075 CrossRef Search PubMed

13. M. G. Ancona, S. E. Kooi, W. Kruppa, A. W. Snow, E. E. Foos, L. J. Whitman, D. Park and L. Shirey, Nano Lett., 2003, 3, 135-138 CrossRef CAS Search PubMed Find@uow.

14. S. Koike, T. Fujieda, T. Sakai and S. Higuchi, J. Power Sources, 1999, 81-82, 581-584 CrossRef CAS Search PubMed FinD@uow:

15. A. Tranchant, R. Messina and J. Perrichon, J. Electroanal. Chem., 1980, 113, 225-232 CrossRef CAS Search PubMed Find@uow:

16. M. S. Whittingham, J. Electrochem. Soc., 1976, 123, 315-320 CAS Search PubMed Find@uow:

17. J. M. Cocciantelli, J. P. Doumerc, M. Pouchard, M. Broussely and J. Labat, J. Power Sources, 1991, 34, 103-111 CrossRef CAS Search PubMed FIND@uow.

18. J. Galy, J. Solid State Chem., 1992, 100, 229-245 CrossRef CAS Search PubMed Find@uowO.

19. R. J. Cava, A. Santoro, D. W. Murphy, S. M. Zahurak, R. M. Fleming, P. Marsh and R. S. Roth, J. Solid State Chem., 1986, 65, 63-71 CrossRef CAS Search PubMed Find@uow:

20. J. Labat and J. M. Cocciantelli, French Patent Application, 1989, 8916337 Search PubMed

21. C. J. Patrissi and C. R. Martin, J. Electrochem. Soc., 2001, 148, A1247-A1253 CrossRef CAS Search PubMed Find@UowO

22. K. E. Swider-Lyons, C. T. Love and D. R. Rolison, Solid State Ionics, 2002, 152-153, 99-104 CrossRef CAS Search PubMed Find@uow:

23. A. Singhal, G. Skandan, G. Amatucci, F. Badway, N. Ye, A. Manthiram, H. Ye and J. J. Xu, J. Power Sources, 2004, 129, 38-44 CrossRef CAS Search PubMed Find@uow.

24. M. Koltypin, V. Pol, A. Gedanken and D. Aurbach, J. Electrochem. Soc., 2007, 154, A605-A613 CrossRef CAS Search PubMed

25. S. H. Ng, S. Y. Chew, J. Wang, D. Wexler, Y. Tournayre, K. Konstantinov and H. K. Liu, J. Power Sources, 2007, 174, 1032-1035 CrossRef CAS Search PubMed Fino@uow.

26. Y. Fujita, K. Miyazaki and C. Tatsuyama, Jpn. J. Appl. Phys., 1985, 24, 1082-1086 CrossRef CAS Search PubMed

27. S. Kobayashi, T. Takemura and F. Kaneko, Jpn. J. Appl. Phys., 1987, 26, L1274-L1276 CrossRef CAS Search PubMed Find@uow.

28. D. Wruck, S. Ramamurthi and M. Rubin, Thin Solid Films, 1989, 182, 79-86 CrossRef CAS Search PubMed Find@uow:

29. B. B. Lakshmi, C. J. Patrissi and C. R. Martin, Chem. Mater., 1997, 9, 2544-2550 CrossRef CAS Search PubMed Find@uowo.

30. B. Alonso and J. Livage, J. Solid State Chem., 1999, 148, 16-19 CrossRef CAS Search PubMed Find@uow:

31. Z. J. Lao, K. Konstantinov, Y. Tournayre, S. H. Ng, G. X. Wang and H. K. Liu, J. Power Sources, 2006, 162, 1451-1454 CrossRef CAS Search PubMed Find@uow. 
32. B. Schimmoeller, H. Schulz, S. E. Pratsinis, A. Bareiss, A. Reitzmann and B. Kraushaar-Czarnetzki, J. Catal., 2006, 243, 82-92 CrossRef CAS Search PubMed Find@uow:

33. R. Jossen, M. C. Heine, S. E. Pratsinis, S. M. Augustine and M. K. Akhtar, Appl. Catal., B, 2007, 69, 181-188 CrossRef CAS Search PubMed Find@uow:

34. T. J. Patey, S. H. Ng, R. Büchel, N. Tran, F. Krumeich, J. Wang, H. K. Liu and P. Novák, Electrochem. Solid-State Lett., 2008, 11, A46-A50 CrossRef CAS Search PubMed Find@uow:

35. L. Mädler, H. K. Kammler, R. Mueller and S. E. Pratsinis, J. Aerosol Sci., 2002, 33, 369-389 CrossRef CAS Search PubMed

36. P. Novák, W. Scheifele, F. Joho and O. Haas, J. Electrochem. Soc., 1995, 142, 2544-2550 CAS Search PubMed FiNo@uow:

37. B. Schimmoeller, H. Schulz, A. Ritter, A. Reitzmann, B. Kraushaar-Czarnetzki, A. Baiker and S. E. Pratsinis, J. Catal., 2008, 256, 74-83 CrossRef CAS Search PubMed Find@uow:

38. S. E. Pratsinis, W. H. Zhu and S. Vermury, Powder Technol., 1996, 86, 87-93 CrossRef CAS Search PubMed FiND@uow:

39. R. W. Cheary and A. A. Coelho, J. Appl. Crystallogr., 1998, 31, 851-861 CrossRef CAS Search PubMed Find@uow.

40. M. Broussely, F. Perton and J. Labat, J. Power Sources, 1993, 43-44, 209-216 CrossRef Search PubMed Fino@uow: 